\title{
IDEOLOGIES OF LANGUAGE AT HIPPO FAMILY CLUB
}

\author{
Chad Nilep
}

\begin{abstract}
Ethnographic study of Hippo Family Club, a foreign language learning club in Japan with chapters elsewhere, reveals a critique of foreign language teaching in Japanese schools and in the commercial English conversation industry. Club members contrast their own learning methods, which they view as "natural language acquisition", with the formal study of grammar, which they see as uninteresting and ineffective. Rather than evaluating either the Hippo approach to learning or the teaching methods they criticize, however, this paper considers the ways of thinking about language that club members come to share. Members view the club as a transnational organization that transcends the boundaries of the nation-state. Language learning connects the club members to a cosmopolitan world beyond the club, even before they interact with speakers of the languages they are learning. The analysis of club members' ideologies of language and language learning illuminates not only the pragmatics of language use, but practices and outcomes of socialization and shared social structures.
\end{abstract}

Keywords: Language ideologies, second language acquisition, Japan, education

\section{Introduction}

The analyses in this paper come from participant observation and ethnographic study with Hippo Family Club, a foreign language learning club in Japan and elsewhere. Between 2005 and 2009 I lived and worked with members of various club chapters in Osaka, Kyoto, Yokohama, and Tokyo, Japan, and in the US state of Massachusetts. This paper, which analyzes club members' beliefs about foreign language teaching and learning, is based on those experiences.

Members of Hippo Family Club in Japan explicitly criticize foreign language teaching in Japanese schools. They contrast these methods, which are described as intimidating, uninteresting, and ineffective, with their own club activities. This paper does not, however, evaluate either the Hippo approach to learning or the teaching methods used in schools in terms of their effectiveness. Instead, it is primarily concerned with the ways of thinking about language that club members come to share. Specifically, members reject the study of grammar as an academic subject, a view of language I label "language as physics". Instead, they pursue a method they call "natural language acquisition", which eschews explicit study of vocabulary or grammar. Members view tagengo 'multiple languages' as routines or practices that afford them access to a transnational sphere. Members suggest that participation in the club links them both to their own chapter and to a "transnational" organization that transcends the boundaries of the nation-state.

\section{Encountering the Club}

Hippo Family Club is a language learning organization headquartered in Tokyo, Japan, with affiliated groups in Korea, Mexico, and the United States. Individual club 
chapters, which in Japan are called "families" with the English loan word, generally meet once per week so that members can practice speaking multiple foreign languages together. At the time this research was carried out, there were club chapters in 45 of Japan's 47 prefectures, representing hundreds of thousands of individual members. Nevertheless, Hippo Family Club is far less visible in Japan than the large, for-profit eikaiwa 'English conversation schools' that, like Hippo, promise participants a chance to learn a foreign language.

When they join the club, members buy a set of recordings, which they listen to at home prior to club meetings. These recordings contain a story translated into seven languages: Chinese, English, French, German, Japanese, Korean, and Spanish. On each $\mathrm{CD}$ the languages are mixed so that, for instance, you might hear the title of the story given in English, followed by a scene in which the characters speak Chinese, another in which they speak French, and so on. Club members believe that listening to these recordings allows them to acquire multiple languages "naturally", in much the same way that children growing up in multilingual societies do.

In addition to listening to recordings, members participate in weekly meetings at local club chapters. These meetings resemble children's play groups, with members dancing or playing games - often variations on the game of tag - while listening to recordings of folk songs or children's songs in the various languages they are learning. Following this warm-up phase, each member of the club is encouraged to speak in the target languages. Members volunteer to give short, memorized speeches, and listeners are expected to offer back-channel feedback in the target language. While interacting with their fellow club members, individuals can both practice speaking the languages they hear on the recordings, and hear the speech of their fellow club members.

International exchange, the third element of Hippo practice, involves either going abroad or hosting foreign visitors. Junior or senior high school students can spend a year abroad, and participants of any age can join short trips overseas. Popular destinations for these sojourns include Korea, Mexico, and the United States, where there are local Hippo organizations, as well as sites in China, Europe, and other places where the club partners with civic or educational groups.

My observations of Hippo Family Club began in 2005 while I was studying at the Japan Foundation's Kansai International Center south of Osaka. During that time, I was introduced to Mrs. Tanaka, ${ }^{1}$ a Hippo Club "fellow" or leader of an individual club chapter. At the invitation of Mrs. Tanaka, who I came to know by the club nickname "Sky", I joined a Hippo chapter and participated in their activities each week. The initial period of observations lasted approximately five months. Later, thanks to support from the Japan Foundation, the National Science Foundation, the Department of Linguistics at the University of Colorado, and innumerable Hippo Family Club participants and facilitators, my observations would continue over a period of five years.

\section{Hippo Family Club and teaching}

Hippo Family Club explicitly contrasts its activities with formal teaching and learning. Both club materials and individual members note that the club has no teachers, a point I return to in section 4, below. This "no teachers" discourse positions the club in

\footnotetext{
${ }^{1}$ The names and nicknames used for individuals and for club chapters are pseudonyms.
} 
opposition to two much larger institutions in Japanese society: schooling, and the eikaiwa industry.

The eikaiwa 'English conversation' industry is a huge commercial undertaking in Japan, with companies competing all over the country to attract students. According to Philip Seargeant (2006) the industry attracts students of all ages from all segments of society through heavy advertising, grossing hundreds of billions of yen in total sales. While the teaching methods utilized by eikaiwa services vary greatly, as commercial enterprises these companies tend to promote and sell the image of their teaching staff. Advertising materials frequently highlight their foreign-born, Caucasian, native Englishspeaking staff. As Seargeant notes, "Their commercial popularism means that [eikaiwa] are the propagators of stereotypes, drawing on pre-existing attitudes within society and then moulding these into a cohesive and influential narrative of the aspirational benefits of education" (2006: 334). These aspirations are not strictly linguistic. As Ingrid Piller and Kimie Takahashi (2006) have described, Japanese learners' desire for English is often confounded with a romantic desire for foreign men, who are stereotyped as handsome, glamorous, sophisticated, and sensitive. Indeed, advertising materials for eikaiwa in Japan often highlight teachers as young, attractive, Caucasian men.

The highlighting of teachers' racial and national identities I saw in eikaiwa advertising in Japan reminded me of my experience as a substitute assistant teacher at a Hiroshima junior high school a decade earlier. The job did not involve any actual teaching on my part. Rather, the classroom teacher lectured in Japanese for the better part of an hour on English grammar, during which time my job was to read aloud example sentences from the textbook. I had not been offered the job, it seemed, for my teaching ability but due to my perceived authenticity as an English-speaking American. In this classroom, at least, the assistant teacher seemed to function to authenticate the international character of English lessons, while their pedagogical value was in the Japanese-speaking teacher's grammar description and the workbook exercises the students carried out while he spoke.

This division of value, with English grammar described in Japanese and the foreign assistant providing model specimens, reflects a traditional view of language learning in Japan. In this view, language is seen as something similar to inorganic chemistry or Newtonian physics: a world of interacting elements that follow particular rules or laws in their interactions. Just as the way to learn chemistry is to memorize the elements of the periodic table and to understand stoichiometry, the way to learn English is to memorize a list of words and to understand grammar, in the sense of rules governing the interaction of linguistic elements. I will call this understanding of language, and the approach to language learning that grows out of it, "language as physics". This view contrasts with the understanding of language learning underlying Hippo Family Club practices, which club organizers and members refer to as "natural language acquisition". The language-as-physics ideology highlights the learning of pedagogical grammar models as an academic goal in its own right, with success measured by entrance exams and standardized tests, among other measures. In contrast, Hippo rejects grammatical analysis or vocabulary study. Hippo Club members contrast their "natural" practices with classroom routines, noting for example that the group has no tests.

The different approaches to language learning in Japanese schools and in Hippo Family Club are based on different understandings of the function of language in society. In the former case, language, and especially grammar, is seen as a form of 
scholastic knowledge and a key to access further academic and economic opportunity. In the latter case, languages are seen as sets of practices, sets of utterance, which bind their speakers to one another. Members of Hippo Family Club see their own multilingualism, with its binding force, as their key to a cosmopolitan realm of interlinked communities.

The ideological construction of what learning is and how it occurs is central to discussion in the following sections. Similarly important are discourses identifying a single national language with the nation-state, against which Hippo's view of multilingualism may be seen as a reaction. ${ }^{2}$ These discourses include twentieth century political and scholarly work in Japan connecting language, ethnicity, and nationalism, as well as the contemporary ideas of language and national identity that succeed them. Hippo Family Club presents a critique of foreign language learning in Japan, which is implicitly a critique of dominant language ideologies in Japan. Hippo members argue that the dominant approach in Japanese schools is unnatural and ineffective. In turn, club members display their own ideologies of language and of language learning. Curiously, while the Hippo Family Club approach to language learning seems to draw on innatist theories of language acquisition (e.g. Chomsky 1972, Lenneberg 2004), at times members' descriptions recall interactional theories that challenge this view of language as innate (e.g. Ochs and Schieffelin 1984, Tomaselo 2003). Ultimately, club members appear to view language not as a capacity for the creation of utterances nor the exchange of ideas, but as a set of practices to be deployed in order to achieve social positioning.

\section{Ideologies of language and learning}

Language ideologies are the conceptions of language and discourse held by individuals or societies, including metalinguistic discourses and the supposed links between social structures and particular languages, styles, or discourses (Errington 2000). The study of language ideologies has emerged as an important current in scholarship since the late twentieth century, encompassing critiques of social structures enacted through discourse (e.g. Bourdieu 1977, Hill 1985) and descriptions of metalinguistic understandings of grammar (e.g. Silverstein 1979) or the place of languages in societies (e.g. Irvine and Gal 2000). More recent studies have analyzed how social practices such as imposing, establishing, and maintaining individual identities (Bucholtz et al. 2012) or constructing hierarchical relations among language varieties and social groups (Davis 2012) rest on ideological linking of semiotic practices. Discourses produced across events at distinct time and places are understood as linked to institutions and identities either through metadiscourse or interactional practices linking individuals or communicative actions to shared ideas.

The particular ideologies that are of interest here are those that underlie or otherwise affect second language learning. Early work by Shirley Brice Heath (1977) offered an insightful explanation of the effect that contrasting ideologies can have on language education and on language planning in general. Heath's investigation of bilingual education in the United States showed a mismatch between teachers' and learners' ideas

\footnotetext{
${ }^{2}$ Discourses linking language to both national identity and the state are noted as an element of nihonjinron (Sugimoto 1999), and are similarly discussed as common, if not essential, in the formation of nations and borders elsewhere (e.g. Anderson 1983, Irvine and Gal 2000).
} 
about the role of education and that of policy makers. Without a shared purpose, the language planning Heath analyzed did not serve the needs of those at whom it was directed, and its implementation was resisted. In a similar, members of Hippo Family Club described frustration with English classes in Japanese schools, and suggested that grammar-centered teaching had led not only to a lack of success but a lack of interest in language learning.

Scholars in various fields have described ideologies around language and nationality in Japan. Communication scholars and foreign language educators have noted that Japanese people who study English as a foreign language usually do not speak the language, even if they can understand spoken English, and read and write it well. Two primary reasons are suggested for this reluctance or inability to speak: the way that English is taught in Japanese schools (Gudykunst and Nishida 1994, Butler and Iino 2005), and ideologies surrounding the relationship between the Japanese language and Japanese identity (Gudykunst and Nishida 1994, Yamada 1997, Downes 2001, Gottlieb 2005).

English language lessons in Japanese schools tend to put a heavy emphasis on the mastery of pedagogical grammars. Although the grammar-translation method of foreign language teaching is no longer advocated in most settings, elements reminiscent of the practice are still visible in junior high school classrooms. Classes are conducted in Japanese, with the grammatical rules of English described in Japanese. Lists of words and grammatical rules are memorized, and success is judged via written tests.

The style of English language learning in Japanese classrooms may discourage students from speaking in two ways. First, the emphasis on written, rather than spoken production in classes and on tests gives students no instrumental motivation to speak the language. In addition, attention to accuracy in testing may make students uneasy to produce the language around others if they judge their own production to be insufficient. I return to discussion of foreign language learning in Japanese classrooms in section 4, where I examine Hippo Family Club's critique of 'traditional' language learning methods.

Ideologies of Japanese language and identity are another factor said to inhibit individuals from speaking English or other foreign languages. Discourses of identity in Japan - discussions of what it means to be a Japanese person - often highlight speaking Japanese as an essential quality. In work by Simon Downes (2001), parents expressed reluctance to send their children to a bilingual junior high school offering partial English immersion, citing, in addition to academic concerns, a fear that their children would lose their sense of Japanese cultural identity after gaining fluency in English. Although the school Downes worked in teaches the same government-approved curriculum that other Japanese junior high schools use, with texts translated into English from Japanese originals, and aims to prepare students for admission to elite universities, many parents are reluctant to enroll their children. By administering questionnaires designed to elicit parents' attitudes about cultural identity, Japan, and the West, Downes found that parents express generally positive attitudes about Western cultures, Western people, and the English language. Yet these parents believe that becoming bilingual will cause their children to be "less Japanese" (Downes 2001: 177).

There is a long history in Japan of popular and scholarly discussions of what makes the Japanese people unique. John Maher (2001) suggests that beliefs in Japanese uniqueness emerged after the closing of the state's borders during the Tokugawa 
shogunate, starting in the seventeenth century. More commonly, scholars date such discourses from the growth of nationalism during the (1868-1912) Meiji period (e.g. Inoue 2006, Lincicome 2009). Discourses of cultural uniqueness and nationalism recur throughout the twentieth century, informing both pre-war militarism and postoccupation reforms of education and government (McVeigh 1998, Lincicome 2009).

Roy Andrew Miller (1982) notes that ideologies about Japanese uniqueness and the uniqueness of the Japanese language were a key aspect of late-twentieth century nationalist discourses known as nihonjinron 'theories of the Japanese people'. Such discourses, most popular during the 1960s and 1970s, equated Japanese nationality with culture and ethnicity (Sugimoto 1999), and sought to describe what makes the Japanese people unique. While such discourses have always been contested as problematic essentialism, the line of thought is visible in late twentieth century government documents and scholarly publications, and especially in popular nonfiction. Alongside descriptions of the "vertical structure" of Japanese social institutions (Nakane 1970) and norms of interdependence (Doi 1973), nihonjinron literature featured speculation about the structure of the Japanese language and its connection to "the essence of the Japanese spirit" (Gottlieb 2005).

While nihonjinron was primarily a twentieth-century intellectual fashion, many contemporary discourses similarly view Japan as a monolingual nation-state. Haru Yamada (1997), a Japanese-born scholar who attended Georgetown University in the United States, describes contemporary Japanese attitudes about language and monolingualism. Yamada summarizes a belief she attributes to her Japanese coworkers: "You are Japanese because you speak Japanese, and if you speak Japanese, you do not indeed you cannot - speak a foreign language fluently" (1997:140). Yamada was regarded by her colleagues in Tokyo as less than truly Japanese because she spoke English. She further suggests that her coworkers related this language ability to her having eaten hamburgers while living in the United States, and thereby internalizing a foreign identity (1997:140).

Discourses in which monolingualism is seen as an index of Japanese identity have two effects on language education in Japan. First, they serve to rationalize the failure of Japanese students to speak foreign languages in spite of years of study by linking monolingualism with authentic Japanese identity. Second, since they place speaking languages other than Japanese beyond the abilities of the typical student, they encourage an approach to foreign language learning that is not centered on speech. Instead, the language-as-physics approach, in which language study is based on the analysis of pedagogical grammars, becomes a proper substitute.

Hippo Family Club espouses an approach that is contrary and perhaps resistant to dominant discourses of foreign language learning in Japan. Hippo sees languages not primarily from the perspective of grammar as rule governed behavior, but in terms of producing locally appropriate utterances. The next section explores Hippo Family Club discussions of language use, particularly discussions that contrast Hippo activities from schools and other 'traditional' learning practices.

\section{Hippo ideologies of language learning}

As described above, dominant educational discourses in Japan reveal a view of language learning as essentially similar to the learning of other academic subjects, 
particularly the natural sciences. I call this view language as physics since, like the teaching of physics at the secondary school level, it pays particular attention to scientific models with relatively little concern for application. Although I cannot claim that my experiences are representative of educational practice in Japan, in the junior high schools and high schools that I observed, English was taught daily, but oral communication - speaking and listening to English - was practiced only once per week and was not usually tested. The lack of testing in oral communication and the emphasis on testing in other areas of the curriculum seemed to suggest that speech was a nonessential element of foreign language study.

Based on published accounts, there is reason to expect that my observations are not out of line with norms in Japanese schools. All junior high schools and high schools in Japan teach English according to national curriculum guidelines set out by the Ministry of Education, Culture, Sports, Science and Technology (MEXT) (Butler \& Iino 2005). In addition, nearly all high school and college entrance examinations test English reading and grammar knowledge (Butler \& Iino 2005). As a result, most Japanese people are obliged to learn English. ${ }^{3}$ Learning English, however, does not necessarily entail speaking English. For many people, the goal appears to be simply to understand the pedagogical grammar of English in order to pass entrance exams.

In the language-as-physics understanding, the elements of language - corresponding roughly to words and affixes - are analogous to elementary particles. Grammar, then, is analogous to physical laws, which determine how elements interact. An understanding of language as a set of elements whose interaction is described by grammatical rules is not wrong - indeed, it is essentially the understanding developed by the founders of the academic discipline of linguistics. The direct application of such meta-linguistic understanding to foreign-language learning is, however, not without controversy. Some applied linguists and language teachers suggest that explicit grammar teaching is advantageous to learners, particularly in the acquisition of relatively simple grammatical structures (Ellis 2002). Other scholars, however, argue that grammars are a theoretical model of linguistic competence, not competence itself. Furthermore, studies have generally found that teaching grammatical rules in isolation has no positive effect on language ability (Omaggio Hadley 2001).

The "natural" position expressed in Hippo Family Club materials can be seen as a reaction against two sets of discourses: discourses linking Japanese identity to monolingualism, as described in section 3, and late-twentieth century debates over foreign language teaching methods. Hippo Family Club was founded in 1981 by Yō Sakakibara, a progressive English teacher and student of generative linguistics. One goal of the Hippo founders was to encourage the learning of multiple languages in order to subvert the monolingual ideology described above.

Contemporary Hippo Family Club discourses - those expressed in learning materials, advertisements, etc. - reject what they label the "traditional" method of language learning. LEX Institute, Hippo Family Club's organizer and publisher, calls the "traditional classroom" ineffective on their English-language web site, and suggests that the focus on grammar and vocabulary that characterizes such classes is futile or somehow inappropriate.

\footnotetext{
${ }^{3}$ According to Butler and Iino (2005) 97\% of Japanese adolescents go on to attend high school after completing compulsory education through junior high school. In addition, approximately 50\% of high school graduates pursue higher education.
} 
Our research shows that anyone, at any age, can acquire new languages. Unfortunately, the way most people usually attempt to learn a language, in a traditional classroom, does not provide a conducive setting for language acquisition. Infants don't learn their native language by breaking the language down into little pieces of grammar and vocabulary, or by looking in a dictionary, so why should a child or adult learn other languages that way either? (LEX Institute 2007)

The "traditional classroom" is implicitly compared to Hippo methods. According to LEX Institute, "HIPPO Family Club has been investigating this natural language acquisition process" by which children acquire their first language. Thus, the Hippo method is presumed to be "natural", while other methods are not.

Another opposition between Hippo learning and the traditional classroom is in arrangements of status and power. The Hippo tape Anyone Can Speak 7 Languages features short essays about Hippo Family Club written by club members and translated into various languages (Hippo Family Club 1997). The track "No Classes, No Teachers, No Tests!" includes a club member's comparison of her children playing in a park with her own experience in school. According to the essay, the member was initially surprised to see "blond-haired, blue-eyed children" speaking Japanese while playing in a Tokyo park. On reflection, she reasoned that the children must have acquired the language while playing with Japanese-speaking children, and suggests that Hippo Family Club approximates such second-language acquisition.

In the park, there were no language study corners for "Lesson 1" and "Lesson 2," no curriculum, no division of class according to ability. And of course, there was no teacher, no tests, and no need to worry about mistakes. There was only the desire to join with favorite friends to build a community. The children did not concern themselves with skin color, or differences between countries. (Hippo Family Club 1997)

This essay echoes the message that traditional learning differs from the natural process of language acquisition, here focusing on second-language acquisition. The essay also resonates with a notion frequently mentioned by Hippo Family Club members: Hippo has no teachers, and all members are equals.

In official club materials and in the testimony of club members, a set of oppositions appears between school and other "traditional" activities versus Hippo activities. Table 1 summarizes these oppositions. In materials produced by LEX Institute, the style of learning used in Hippo Family Club is regularly contrasted with "traditional" learning methods. Implicitly, then, Hippo activities must be innovative or new, in opposition to methods used elsewhere. While the word "tradition" does not necessarily hold negative connotations, these discourses go on to characterize the traditional approach negatively, as in the example quoted above where it is argued that traditional methods are not "a conducive setting for language acquisition" (LEX Institute 2007). This reference to "acquisition," along with frequent descriptions of Hippo activities as "natural acquisition" based on research in "natural science," and of language acquisition as something that occurs in a "natural setting" (LEX Institute 2007), further implies that 
traditional foreign-language study is unnatural or artificial. This contrast does rely in part on the positive connotations of the word "natural" to build an understanding of Hippo activities as positive and superior to other approaches.

\begin{tabular}{|c|c|}
\hline School activities & Hippo activities \\
\hline "traditional" & innovative \\
\hline unnatural & "natural" \\
\hline "grammar and vocabulary" based & utterance based \\
\hline $\begin{array}{l}\text { atomistic } \\
\text { "breaking the language down" }\end{array}$ & $\begin{array}{l}\text { holistic } \\
\text { "from the whole" }\end{array}$ \\
\hline teacher-centered & $\begin{array}{l}\text { learner-centered } \\
\text { "no teachers" }\end{array}$ \\
\hline divided by ability & "no division of class according to ability" \\
\hline high-pressure & $\begin{array}{l}\text { low-stress } \\
\text { "no need to worry", }\end{array}$ \\
\hline "not conducive for language acquisition" & presumed effective \\
\hline
\end{tabular}

Table 1. Comparison of school activities with Hippo activities. Folk terms used by members or in club materials appear in quotation marks.

In addition to the positive connotations of natural learning, these discourses offer a description of traditional learning that is not only generally unappealing, but that places blame for any past failure to acquire foreign languages on teaching methods and the theories underlying them, rather than on the learner herself or himself. The methods that Hippo rejects are atomistic, "breaking the language down into little pieces of grammar and vocabulary" (LEX Institute 2007). In contrast, Hippo methods work "from the whole to the parts" and do not call upon the learner to analyze, memorize, synthesize, or otherwise engage in scholarly activities that may be associated with past academic failures. Teachers, too, are absent from the Hippo experience, and with them any opportunity for teacher-centered classes. Even classes are eschewed in favor of "Language Experience, Experiment \& Exchange" (LEX Institute 2007), the expression from which LEX takes its name. This discourse of egalitarian, communal learning is presented as not only more effective than classroom learning, but also lower in stress and more fun. In all, the image that LEX and Hippo materials present of learning based on an understanding of language as physics is dreary and off-putting, while Hippo Family Club is drawn as an amusement as well as a presumably effective means of language learning.

In contrast to the language-as-physics ideology that appears to underlie English teaching in schools, Hippo Family Club members talk about "natural language acquisition" in terms borrowed from linguistics and psychology. Members also focus on learning particular texts, especially the content of club recordings, as a means to achieve this acquisition.

One of the central activities of Hippo Family Club practice is listening to club recordings. The most frequently used recordings present stories about the lives and activities of Hippo Family Club members, which are translated and repeated in multiple languages. Members listen to these recordings repeatedly, and eventually memorize their content. The point of all this listening is not to focus on individual words or 
common patterns, nor is it expected that the listener will come to any understanding of the grammatical rules underlying the languages used. Throughout my interactions with club members I heard no explicit talk about grammatical rules as such. Occasionally, however, members would offer impressionistic descriptions of particular languages, or make broad comparisons of languages.

The point of listening to recorded stories is not even to understand the plot, though of course members do come to know the stories well, and sometimes allude to them when talking to other club members. Rather, LEX invites members to participate with the instruction nami Ni nottemiru 'try to ride the wave', that is, experience the overall pattern of speech sounds. "Without understanding the precise meaning, enjoy the sounds - ride the wave of words" (LEX Institute 2007, my translation). Similarly, during metakatsu, an activity in which members recite the content of the CDs together in unison, the intent is to reproduce the kotoba no nami 'wave of words' as it appears on the CDs. After repeated attempts, members reproduce the stories in the exact words that appear on the CDs, following the same prosodic pattern of accent and timing. During early stages, before the words have been learned, members mimic the general prosody of the CD tracks. The CDs thus constitute a set text to be internalized and reproduced.

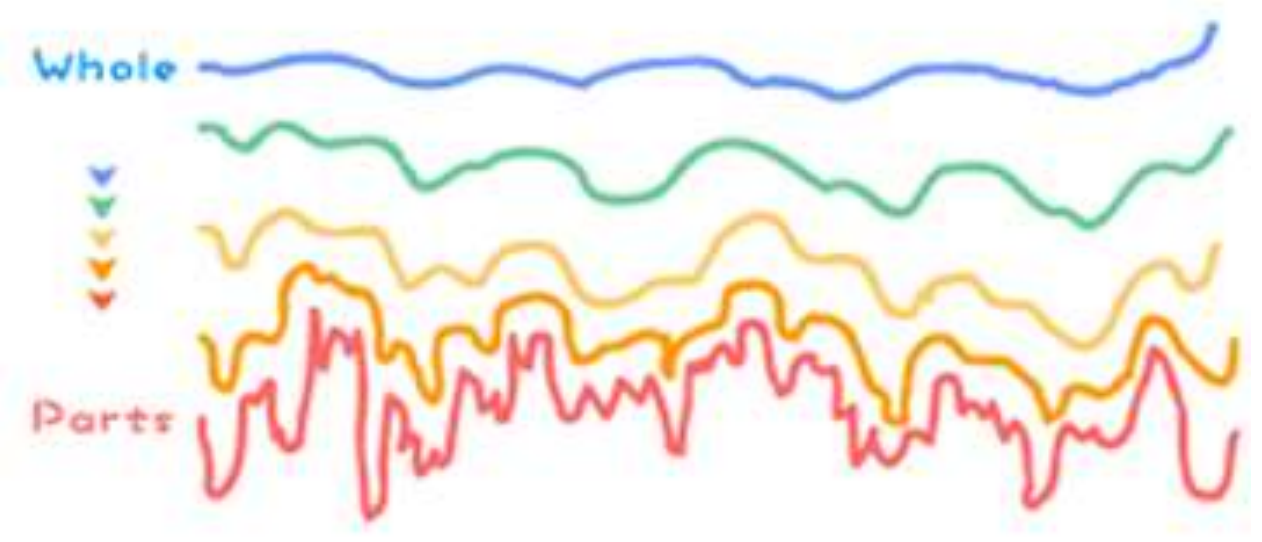

Figure 1. "From the whole to the parts" (LEX Institute 2007)

This image of "waves" commonly recurs in Hippo meta-discourse, that is, when Hippo members and officials talk about Hippo Family Club. On the LEX web page that encourages members to "ride the wave of words" there appears an image meant to illustrate the Hippo approach to language acquisition called "from the whole to the parts" (Figure 1). The text that accompanies the graph suggests that it is an abstract illustration of the developmental stages of first language acquisition.

We call this natural process of language development "from the whole to the parts." When babies babble in baby-talk, they are mimicking the broadest outline of the language. Later, they begin to speak in phrases, but may only pronounce the sounds at the beginning and end of a phrase while humming through the rest. Eventually, they are able to be more precise in their sounds and phrases, until they become a mature speaker. (LEX Institute 2007, original emphasis) 
The description of "babble" followed by "phrases" and eventual "mature [speech]" roughly accords with the descriptions of developmental stages in first language acquisition, as described by linguists and psychologists. Eric Lenneberg's (2004) influential work on first language acquisition, for example, describes "babble" emerging in child language production around six months, "two-word phrases" at 24 months, and speech resembling adult language after three years. The series of downward arrows along the left side of the LEX illustration suggests, albeit in a vague way, a progression through time parallel to that given by Lenneberg's increasing ages. Thus, on one level, it is possible to see the increasingly wavy lines, whose colors correspond to those of the arrows, as abstract depictions of increasingly complex or adult-like language production. At the same time, LEX prescribes its "from the whole to the parts" progression as an approach for adults as well as children to use in second-language learning. The abstract description of this progression seems to lead to a diversity of understandings among Hippo members.

The uncertain and highly variable understandings of language acquisition that Hippo Family Club member draw from LEX's descriptions can be seen in the presentation and discussion of similar illustrations. At various public meetings to recruit new members I have seen club leaders draw images very similar to the "From the whole to the parts" illustration on the LEX web site. What is interesting is the ways in which their descriptions of the illustrations differ from that offered by LEX. Figure 2 shows an illustration very similar to the one included on the LEX web site. The drawing is from my own field notes; it is my reproduction of a hand-drawn picture shown at an event in Osaka prefecture. The original was in three colors: the broken line at the top in red, the wavy line at the bottom and the X-Y axes in black, and the intermediate lines in blue. Under the graph, also in black ink, is the legend オシログラフ 'oscillograph'.

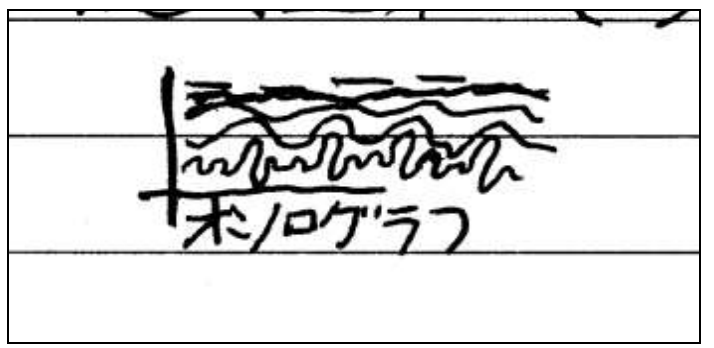

Figure 2. "Oscillograph" drawing from Osaka presentation. Author's field notes, 30 November 2008.

The speaker, a chapter leader, used the drawing in her lecture on the nature and effectiveness of Hippo activities. In her lecture, she suggested that the red line illustrates babies' vocalizations, though whether that meant crying or cooing was not clear. She did not explicitly describe what the various blue lines were meant to illustrate, though she did suggest that the lower black line described fully developed speech. While the original image by LEX Institute was an abstract illustration of the relative simplicity of early language production, this presenter suggested that the graph measured some actual physical oscillation, as shown by the "oscillograph" legend that she added to the image. Where the LEX web site offered an abstract visualization of general observations, this member used the same image to provide an air of scientific legitimacy and empirical measurement to her persuasive speech. 
At another meeting, elsewhere in Osaka prefecture, I noted a speaker who drew a similar illustration by hand, and gave an even more intricate description of its meaning.

The member who did the kouen (public speech) drew the now-familiar 'waves' graph: a two-dimensional graph with a flat, broken line at the top, a regular sine wave of relatively small amplitude below that, and a slightly more complex but very regular wave of greater amplitude at the bottom. As usual, she said that the flat broken line represents baby's 「ギャー ギャー」 [gyaa gyaa], the second the speech of toddlers, and the bottom adult (-like) speech. But then she went on to draw additional, slightly different sine waves overlapping the middle one and said that we each sometimes speak differently. (Field notes, 28 November 2008)

This speaker seemed to understand the wavy lines as abstract illustrations of increasing complexity, and not as instrumental measurements of sound waves or other oscillation. She also shared the understanding that this increasing complexity is a depiction of children's first language acquisition in general, as suggested on the LEX web site. She soon betrayed an uncertainty of what the image illustrated, however. First, the presenter added another sine wave overlapping the intermediate line in the illustration, but did not suggest what the line represented. A short time later she added two different legends to the chart's y-axis. On the left side of the graph, she wrote zero sai 'age zero', ni sai 'age two', and otona 'adult' next to the top, middle, and bottom lines, respectively, echoing LEX's description of the graph as an illustration of the increasing complexity of firstlanguage acquisition. In addition, though, the speaker labeled the top line with the character for watashi 'me' on the right-hand side. Next to the middle ni sai line she added the characters for nakama 'group, circle of friends', and next to the bottom otona line she wrote the roman alphabetic characters $C D$ (presumably for Compact Disc). While she was writing, she explained that the individual is in some way equivalent to a baby acquiring its first language, but she did not elaborate on this metaphor. The speaker betrayed some unease with her own explanation by frequently turning away from the audience to regard her drawing as she spoke. After the meeting, she confessed to me that she had been uncertain of her explanation and feared that she hadn't described the club activities properly.

Clearly, the "wave" illustration can be understood in various ways by club members. Furthermore, it seems that those understandings are as elusive and ineffable as they are variable. Where the LEX Institute web page seems to intend its drawing merely as a graphic illustration of the general pattern of first- and second language acquisition, in which the speaker's grammatical competence and linguistic output gradually become more complex, members seem to take the drawing as an index of scientific authority. The club fellow who labeled a similar drawing "oscillograph" may have believed that she was reproducing a discourse that relies on "researching the natural sciences of humans and language" (LEX Institute 2007), which LEX Institute suggests is the basis of Hippo practice. The club member who equated various elements of her drawing both with stages of first language acquisition and with elements of Hippo Family Club practice and membership seemed to have some idea that Hippo is in some sense equivalent to first-language acquisition. Yet it is clear that she did not have a specific understanding of what this equivalency entails. 
Hippo members' practice of memorizing texts as part of language learning is in some ways at odds with the notion of creativity as expressed, especially, in generative linguistics (e.g. Chomsky 1972), but also in subsequent descriptions of communicative competence (e.g. Hymes [1972] 2001) and the pedagogical models that derive from them. Noam Chomsky (1972) defined creativity in language as the ability to generate a potentially infinite set of linguistic structures from a finite set of grammatical properties. Del Hymes (2001) expanded this notion by pointing out that human beings do not simply generate sets of linguistic structures, but adapt their language behavior to situations and interlocutors as necessary. Thus communicative competence consists not only of the ability to produce grammatical utterances ("creativity" in Chomsky's sense), but also of the ability to creatively adapt linguistic behavior to the needs of particular interactions. These notions of communicative competence and creative adaptation, in turn, inform communicative approaches to foreign language teaching and learning.

The approach to language learning in Hippo Family Club does not stress creativity in either the Chomskian or the Hymesian sense. Hippo activities treat target languages as, in the first approximation, sets of utterances that can be memorized and repeated, without particular adaptation to the moment of speaking. Club members listen to the same CDs again and again, and exercise their content repeatedly at weekly meetings. In this way, they suggest, they will be able to produce appropriate responses to linguistic stimuli. This description is rather reminiscent of behaviorist theories of language acquisition from the first half of the twentieth century, and the Hippo method appears similar in some respects to the audio-lingual method of teaching popular from the Second World War until the 1960s. Like audio-lingual-method teaching, Hippo recommends frequent repetition of patterns without explanation of grammar. Critics of the audio-lingual method suggest that it keeps learners at a novice level indefinitely, since it does not call for any creative use of language, relying instead on repetition of previously memorized patterns (Omaggio Hadley 2001). Given that a frequently stated goal of Hippo Family Club members is basic-level communicative ability in a large number of languages, however, it is not surprising that few Hippo members see this as a serious disadvantage. ${ }^{4}$

Some understanding of the stance of such members is provided by an oft-told genre of story that I identify as the "surprised by competence" narrative. At a schematic level, this narrative has three basic components. First, the narrator describes listening intently to CDs and practicing metakatsu (Hippo-style recitation, literally 'meta-activity'), or professes a special interest in a particular target language. Next, the narrator confesses that she or he did not believe that any real language ability was developing. Finally, however, the narrator describes an experience with the target language outside of weekly Hippo meetings, often during a trip abroad or while meeting a visitor to Japan from abroad. In this climax of the story, the narrator describes being surprised by his or her own ability to speak the language spontaneously in conversation with a native speaker. As more than one story teller put it, the sounds of the Hippo recordings had magically transformed themselves into the words of the target language within the learner's mind. One version of this "surprised by competence" narrative is included in the LEX recording Anyone Can Speak 7 Languages!

\footnotetext{
${ }^{4}$ Many members have a basic knowledge of several languages, though most take a special interest in one or two languages, which they pursue more deeply.
} 
Last summer, at my husband's insistence, I agreed to go to France on a homestay, but I dreaded the thought of it. For six months, I reluctantly played the French tapes while endlessly saying to myself, "Je ne parle pas francais." (I don't speak French.)

$[\ldots]$

I was really surprised by my French. Although I had thought I couldn't speak at all, when I was actually compelled to go to France, I had no sense of any language barrier. The French spoken by my host family was very clear and I could understand them easily. (Hippo Family Club 1997)

Where this version of the narrative describes only passive language ability ("I could understand them easily,") Hippo members have told me versions of their own surprising competence in which they claim they were actually able to speak the target language though their reported utterances are generally short phrases.

The "surprised by competence" narratives also illustrate other aspects of club member's ideas about the club and their own language learning. For example, since members often recount having believed that they would not gain the ability to speak a particular language, we can conclude that language learning is not the only goal of club members. If the purpose of joining Hippo Family Club were simply to gain speaking ability, it is unlikely that members would persist in their intense participation despite their disbelief in its effectiveness. In addition, these narratives frequently feature a coda suggesting that "the sounds became words" or that the language had assembled within the speaker's mind without conscious effort or control. Such suggestions echo the claims of "naturalness" described in LEX Institute materials, above.

The practice of memorizing texts has some precedent in Japanese cultural practices. The game of karuta 'cards' is thought to have been introduced to Japan by Portuguese visitors, probably in the mid sixteenth century (Bull 1996). Since gambling was outlawed during the Edo period (1603-1867), however, the form of the cards and the games played with them evolved rapidly. Another, older pastime still popular during the Edo period was reciting or copying the poems from the Hyakunin Isshu 'One Hundred Poets, One Poem Each' anthology compiled by Fujiwara no Teika in the thirteenth century. An even older game, kai-awase 'shell matching', was played by Japanese nobility during the Heian period (794-1185) with sets of clam shells on which pictures had been painted. The object of the game was to match two shells featuring the same image. The game of uta-garuta 'poetry karuta' combines the traditions of Hyakunin Isshu, kai-awase, and karuta (Bull 1996). In the game, a reader recites the first half of one of the poems from Hyakunin Isshu, and the other players race to grab the card on which the second half of the poem is written.

While staying with a family in eastern Japan I was surprised to learn that the family's older daughter, a first-year junior high school student, was required to memorize the Hyakunin Isshu and to play karuta at her private cram school. Although such tasks appear to have gone in and out of fashion among Japanese educators, it is not so unusual to see karuta assigned as a memorization task. Hippo Family Club chapters similarly use forms of karuta games to practice certain language structures. Thus, the practice of learning by memorizing set texts, while not unanimously embraced, nonetheless has precedents in other Japanese educational activities. 
Tasks involving memorization are not unique to Japan, as I was reminded by a Hippo club member. I suggested, during a presentation of my work at a Hippo chapter in Yokohama, that karuta constituted a particularly Japanese approach to learning. A member suggested that her children, who have participated in Hippo Family Club since they were very small, are not only skilled at karuta but also successful in auditioning for school plays, another school activity that requires memorizing texts. Of course, school plays are hardly unique to Japan. I then recalled having to memorize the Preamble to the United States Constitution in my own school days. Although the specifics may differ, memorization has a place in both Japanese and American education.

The language-as-physics ideology frequently seen in Japanese schools and eikaiwa has some negative effects on language learning, particularly in the realm of negative affect. The focus on grammar study and testing does not have particularly positive effects on speaking ability, and the association of foreign language learning with high stakes testing, and the need for precise accuracy that such tests require discourage many foreign language learners from using their foreign language abilities in face-to-face interaction. Hippo Family Club, by treating language as play, avoid some of these negative feelings about speaking foreign languages, and may thus avoid raising affective filters (Krashen 1982).

The orientation of Hippo Family Club members to language acquisition has the potential for both positive and negative effects on language learning. A primary advantage, as suggested above, stems from positive affect. Members regard Hippo activities as play or group social events, rather than describing them as study or work. Members typically continue in the club for many years, allowing themselves far greater time for learning and development. It is also common for members to participate in a range of different activities under the general heading of "Hippo," including listening to recorded materials and participating in weekly meetings, as well as reading Hipporelated books or news letters, contributing to special events, and either going abroad or hosting international visitors. All of these are likely to contribute to incremental language learning.

Another positive effect of Hippo ideology is the description of the activity or subject as tagengo 'multilingualism', as opposed to either a single target language or gaikokugo (literally 'foreign-country language'). While Hippo's discourse of egalitarianism may exaggerate members' actual behavior, in general club members seem positively disposed to interacting with foreign guests. Similarly, with the broad stock of highfrequency phrases the club encourages members to memorize and repeat, they are often able - and quite keen - to communicate in a rudimentary way with people who do not speak Japanese. This willingness to use the target languages in order to communicate is very different from the uncertainty and apparent shyness that too often results from language learning that stresses accuracy.

\section{Karagoku Family}

I have thus far argued that members of Hippo Family Club approach the learning of multiple languages as natural, while relying on memorization and repetition as part of the "natural language acquisition" process. In the view of Hippo Club members, language is not seen in terms of grammatical competence as the cognitive ability to generate linguistic structures (Chomsky 1972). Nor is language viewed in terms of 
communicative competence as the means to interact through language behavior in culturally appropriate ways (Hymes 2001). Neither do members of Hippo Family Club treat language as a set of discourse practices acquired through socialization with which to achieve positioning in a society or group (Bourdieu 1977). Rather, members memorize and reproduce particular speeches in order to emulate the process of language acquisition as they understand it. Members have little or no expectation that they will be able to produce novel utterances in response to an unfolding interaction, at least during the early stages of learning. Practice during Hippo Family Club meetings treats the fluent production of rote texts as a goal.

In this section, I will illustrate this practice by analyzing discourse data from a weekly meeting of Karagoku Family, the chapter I belonged to in Osaka prefecture. The discourse analysis shows the reproduction of a memorized speech that is the goal of interaction during the meeting. With help and extensive co-construction from other club members five-year-old Taro-kun introduces himself in English. Prompts and other contributions from members other than Taro-kun are not treated as relevant to the speech activity. Minimal responses in English are offered only after Taro-kun speaks.

During weekly Hippo Family Club meetings, members frequently present speeches that are modeled on the recording Hippo Goes Overseas (Hippo Family Club 1985). In speeches called jikoshokai 'self-introduction', members give their names, the names of their family members, a brief description of their home, and a list of interests. This content parallels track two of the recording, in which a character introduces herself. In the case of weekly meetings, however, learners produce essentially the same speech each week to fellow club members who already know them well.

In excerpt 1 Taro-kun begins his self-introduction. Taro-kun's mother, Mikan, supplies nearly every phrase of the speech to Taro-kun before he repeats it to the other club members, who are sitting in a circle and listening to him. Mikan's speech is not treated as relevant to the activity, however, as is illustrated by the responses offered by another club member, Tanaka-papa. Tanaka-papa responds in English only after Tarokun has spoken. Taro-kun's contributions are thus treated as appropriate turns in the furtherance of the speech activity, while Mikan's speech is ignored. (English words are transcribed in standard English orthography; Japanese words are transliterated in Roman alphabetic characters. Japanese words are glossed in double parenthesis.)

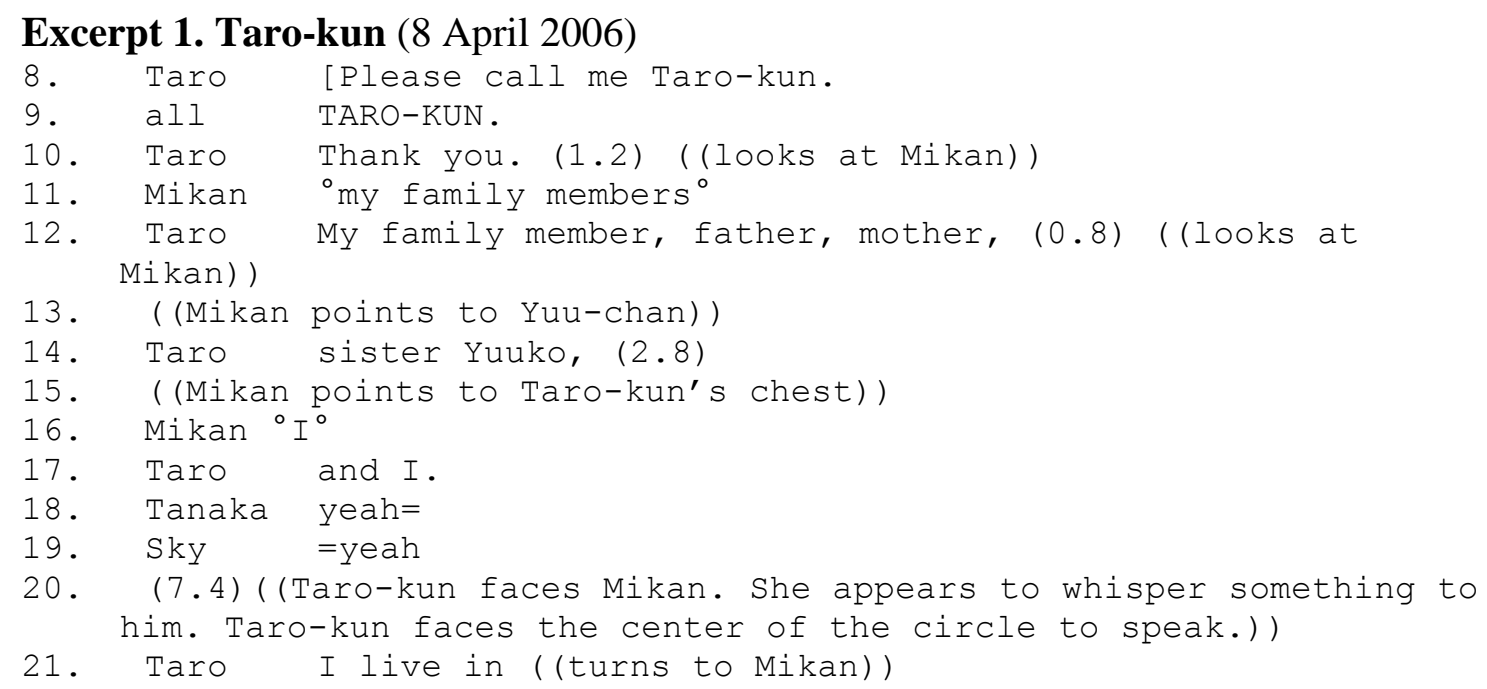




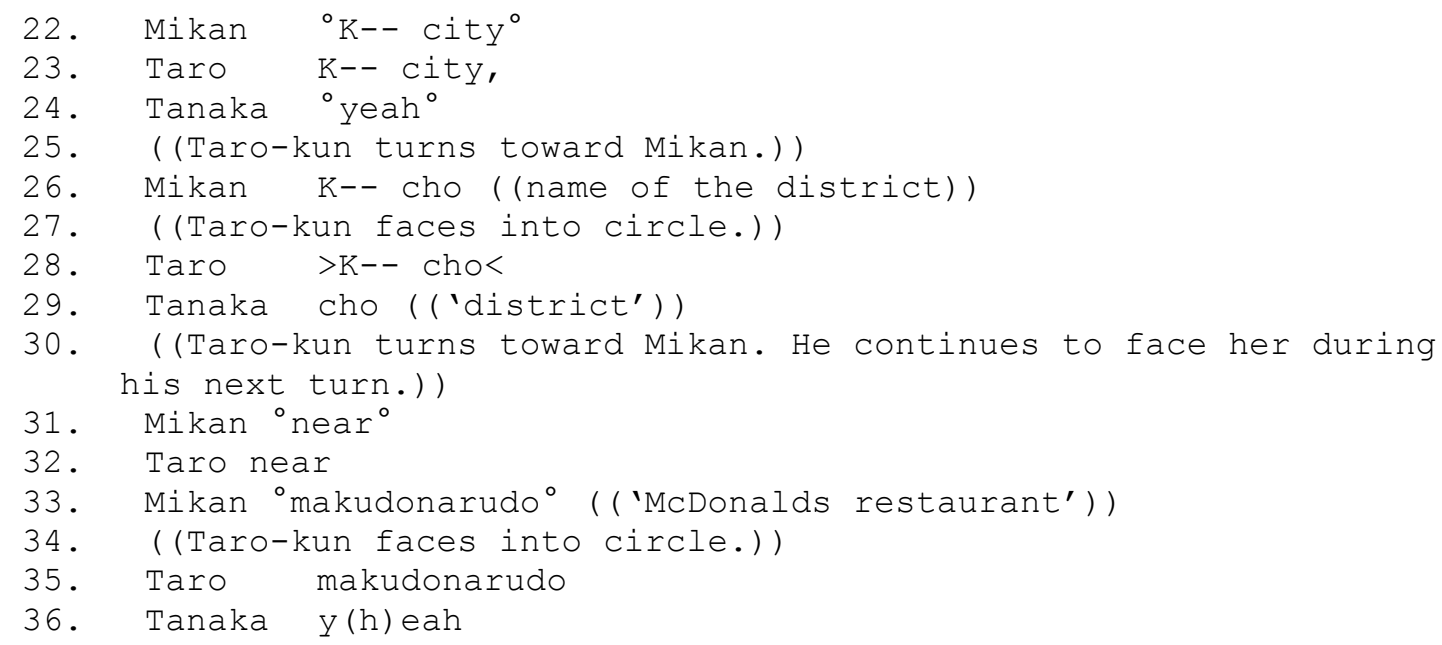

Since Taro-kun's speech is in the genre of jikoshokai, it is expected to follow a standard script. This includes the speaker's name (line 8), a list of his family members (lines 1117) and a brief description of his home (lines 21-35). Tanaka-papa, an adult member of the club, offers minimal responses in English only after Taro-kun has completed an element of this script (lines 18, 24, and 36). Likewise, the chorus of voices saying "Taro-kun" in response to his request to be called by his club nickname (lines 8-9) is a standard part of this speech genre during Hippo meetings.

While Tanaka-papa's responses treat Taro-kun's utterances as relevant, there is no response from Tanaka-papa or others to Mikan's prompts, which help Taro-kun to produce his next line. During this interaction, Taro-kun is sitting on Mikan's lap. He frequently turns to her and she whispers the next words of his speech, which he then repeats into a microphone (lines 12, 17, 21, 23, 28, 32, and 35). Although Mikan speaks repeatedly during this exchange (lines $11,16,22,26,31$, and 33), no response is offered until Taro-kun has spoken. Thus, Taro-kun's speech is treated as on-the-record speech in furtherance of the self-introduction, while Mikan's contributions are treated as backstage prompts, not part of the on-going activity.

Excerpt 2 continues Taro-kun's self-introduction. The content of the jikoshokai conforms to the standard script for this speech genre. Other members of the club know what to expect, thanks both to genre conventions and to the fact that Taro-kun has delivered essentially the same speech every week for the past several months. In excerpt 2, however, Taro-kun and Mikan attempt to elaborate the speech somewhat from that given in weeks past. The addition of a new element, and a slight recall problem in its production occasion a negotiation over the content of the speech.

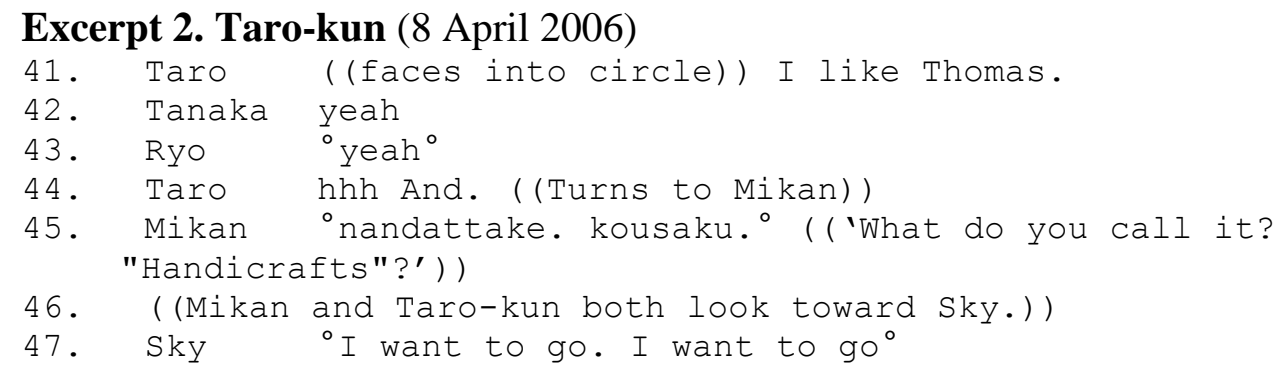




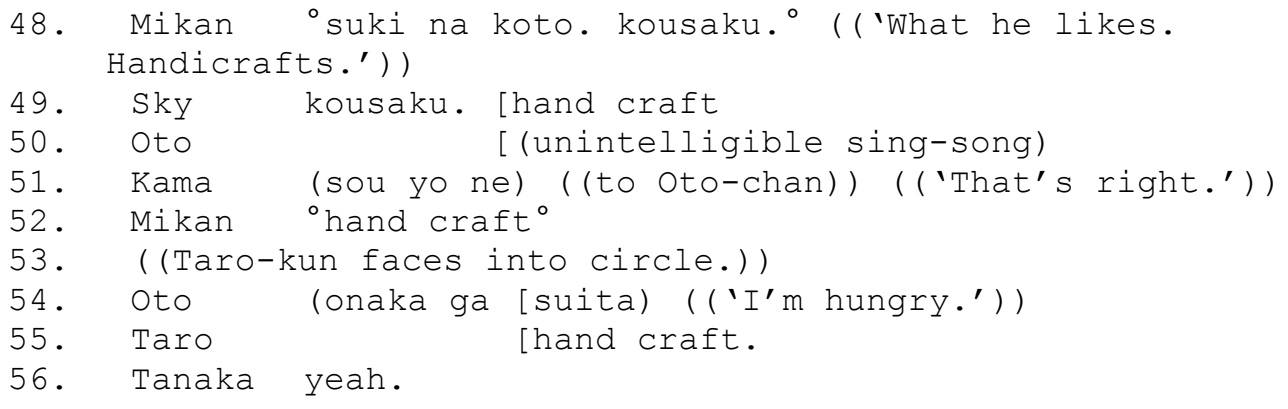

During weeks past, after describing his home Taro-kun has described his interests by saying, "I like Thomas. I want to go to England. I want to meet Thomas," in reference to the cartoon Thomas the Tank Engine, which was popular in Japan at the time. This week, though, he has decided to list two of his interests: watching Thomas and creating handicrafts. When neither Taro-kun nor Mikan can remember the English word handicrafts, however, their appeal to other club members is treated not as difficulty in translating a word from Japanese to English but as difficulty completing the script.

In excerpt 2 , as in excerpt 1 , Mikan tries to help Taro-kun by prompting him, delivering virtually the entire self-introduction along with him. Taro-kun faces away from the circle and toward Mikan after each utterance, inviting her to give him his next line. After she supplies each line, Taro-kun turns back toward the circle and repeats it. At line 44, he produces a single word, "and," before turning to face Mikan. Mikan speaks Japanese, producing an informal interrogative, "Nandattake. Kousaku" 'What was it? Handicraft', inviting others to provide the appropriate English translation of kousaku. When no translation is immediately forthcoming, both Mikan and Taro-kun turn to face Sky, the chapter facilitator.

At line 47 Sky responds not to Mikan's question, "What is kousaku?" but to the expectations of the script. She suggests the next part of Taro-kun's weekly speech, "I want to go." Mikan explains at line 48 that they are attempting to describe another thing that Taro-kun likes: "Sukina koto. Kousaku" "Things he likes. Handicrafts'. Sky translates kousaku as "hand craft." Mikan repeats "hand craft" to Taro-kun before he says it himself at line 55. At line 56, again responding only to Taro-kun, Tanaka-papa offers his usual feedback, "yeah." Despite the participation of Sky and Mikan, the utterance is treated as Taro-kun's accomplishment.

Since Taro-kun is the authorized speaker during this portion of talking time, only his speech production is treated as relevant. Tanaka-papa ignores Mikan and Sky's prompts. In addition, three-year-old Oto-chan's complaints about hunger and fatigue (lines 50 and 54) are generally ignored or treated as a separate speech event. Oto-chan's mother, Kama-chan, responds to her with low volume and does not face into the center of the circle. Like Tanaka-papa, Kama-chan acknowledges that the goal of this portion of the meeting is the realization of Taro-kun's jikoshokai in accordance with the expected script.

Immediately after the talk in excerpts 1 and 2, above, the members of Karagoku Family begin a new discourse activity. Where the prior activity was conceived of as a monologue in English, the latter activity is a multi-party discussion in Japanese. The discussion shows how club members evaluate talk outside of Hippo meetings. Implicit 
in this evaluation is an expectation that memorized discourses will serve the members well in other settings, outside of Hippo meetings.

Immediately after the completion of Taro-kun's jikoshokai, Mikan introduces a new topic, apparently at Taro-kun's request. Mikan announces that Taro-kun delivered a speech, which she labels eigo no uta 'English song' and later jikoshokai. Mikan describes Taro-kun's deployment of his memorized speech as a successful and wellappreciated use of English in a school setting. She reports that Taro-kun's kindergarten teacher invited him to deliver his self-introduction at school. Mikan's initial announcement, peppered with discourse markers and filled pauses, appears hesitant. Additionally, she provides three accounts for the reason that Taro-kun was invited to speak: "Chotto dekiru toka kara" 'because he can a little', "fudan kara" 'because it's his habit', and "eigo narateiru toka kara" 'because he's learning English and so on'. Eventually, she describes what happened, couching the claim in reported speech attributed to Taro-kun's teacher: "Sensei ni 'jikoshokai shite kudasai' to iwarete" 'Teacher said, "Please do your self-introduction"'. In the words that Mikan attributes to the teacher, the speech is called jikoshokai, using the label common during Hippo Family Club meetings. The attribution of the label to the teacher thus aligns her with Hippo discourses, without marking any clear difference from daily kindergarten activities.

The reactions of other club members to this narrative suggest that they regard Tarokun's experience at the kindergarten as a successful accomplishment worthy of celebration. Following Mikan's announcement, Tanaka-papa and Sky both offer strong positive assessments, each using the word sugoi 'great, impressive, enormous'. While Mikan plays down her son's accomplishments, Tanaka-papa and Sky continue to produce lavish appreciations.

As the discussion continues, the club members suggest that the memorization and reproduction of a scripted text is an important goal both in the realm of Hippo activities and in language learning more generally. Another member, Kama-chan, grounds the activity in the realm of kindergarten when she asks which teacher invited the performance. Placing Taro-kun's English in kindergarten - that is, outside of weekly Hippo activities - makes his speaking ability relevant not only to Hippo but to a broader universe of language use. Mikan continues to report speech attributed to the kindergarten teacher: "Nanka kekko nagai no o oboitekure' tte, M-- sensei" 'Ms. M-was like, "Somehow he memorized this long thing for us"'. Mikan reports the teacher's evaluation as oboitekure 'memorize for us', suggesting that memorization is a goal of language learning for the teacher, as it is in Hippo practice. Although LEX Institute materials contrast the Hippo practice of memorizing speeches with the grammar-based study in 'traditional' schooling, in Mikan's recollection the school teacher views such memorization of jikoshokai as an accomplishment worthy of praise.

The discourse around Taro-kun's kindergarten experience suggests that the production of speeches, and not necessarily an ability to interact with others, is a goal. By knowing and reproducing these speeches, club members see themselves as part of a worldwide community of people who produce the same languages. This reproduction need not include interaction with those language users, though. Although a native speaker of English - me - was in the circle during Taro-kun's jikoshokai and the subsequent discussion of his experiences at kindergarten, I was not active in the 
discourse. None of the club members treated me as a resource for English learning or as a potential contributor to the interaction.

This analysis suggests that Hippo Family Club members see the ability to reproduce texts, and not necessarily any ability to interact with fellow speakers, as a goal. This in turn hints at one possible reason for the club's emphasis on tagengo 'multilingualism', as opposed to fluency in any single language. Each text is treated as a formal unity. While a self-introduction in German might have all the same referential components as a similar self-introduction in English, it is the form of the speech that must be committed to memory. The reproduction of the German speech is then the practice that connects the club member to the world of German speakers, just as the reproduction of the English text secures a connection with English speakers. Learning more languages, by memorizing more speeches, promises access to broader sections of the world, even before interacting with speakers of those languages. Club members do, in fact, seem to value their interactions with speakers of foreign languages, as shown by their eagerness to host visitors from abroad or to travel abroad. The global community within which tagengo allows members to envision themselves, however, is larger and more appealing than any set of actual, face-to-face relationships.

\section{Conclusion}

This paper has examined two aspects of language ideology visible among Hippo Family Club members in Japan. In terms of language education, club members contrast their own "natural language acquisition" approach with that of dominant educational institutions. Where most schools and some eikaiwa 'English conversation schools' stress accuracy and fidelity to pedagogical grammars, an approach I have identified as language as physics, Hippo participants seek to acquire language without such study via exposure to recordings and the second-language speech practice of fellow club members.

At the same time, memorization does have an important place in Hippo's approach to language learning. Rather than memorizing a meta-language that consists of grammatical rules and lexical elements, Hippo members memorize key texts, especially the content of LEX Institute's story recordings. By reciting these stories and their own speeches modeled on the recordings, members believe that the natural language capacity of their own minds transforms the sounds of the recorded stories into the structures of the target languages.

Additionally, in terms of more general understandings of the nature of language, Hippo Family Club suggests that the fluent production of appropriate phrases - even if those phrases are pre-compiled and memorized - is speech production. Thus, it is not necessary to understand or to be able to model the underlying grammatical patterns of a language, so long as one can reproduce the appropriate output. Hippo Family Club members pay particular attention to the fluency or fluidity with which utterances are produced, usually without regard for creativity in the sense of "ability to express new thoughts and to understand entirely new expressions of thought" by manipulating grammatical "laws and principles" (Chomsky 1972:6).

As the analysis presented in section 5 suggests, club members celebrate the recitation of memorized speeches, paying particular attention to pronunciation and fluency, and do 
not expect novel or extemporaneous production. Furthermore, the discourse of club members positions such memorized speech production as an appropriate means to interact with non-members, including speakers of the target languages. Thus memorized speeches are at once a means of approximating and of developing the ability to command linguistic structures. Since Hippo Family Club members believe that this human ability is present and complete "from the time the first cell of the egg was produced" (Hippo Family Club 1997), and that all forms of speech production are equally expressions of that general ability, these pre-compiled utterances are considered not only steps toward the acquisition of languages but expressions of natural language ability. It is curious to note that these understandings are at turns consonant with and opposed to the understandings of language expressed by academic linguists.

This paper has described and analyzed Hippo Family Club members' language ideologies, their understandings of the nature of language structure, discourse practice, and language acquisition. By interacting with other club members and reading and listening to the same learning materials, members come to understand language in similar, but not identical ways. The analysis of such language ideologies provides an opportunity to understand not only the pragmatics of language use, but practices and outcomes of socialization, and shared social structures.

\section{References}

Bourdieu, Pierre (1977) The economics of linguistic exchanges. Social Science Information 16(6), 645-668.

Bucholtz, Mary, Brendan Barnwell, Elena Skapoulli, and Jung-Eun Janie Lee (2012) Itineraries of identity in undergraduate science. Anthropology and Education Quarterly 43(2), 157-172.

Bull, David (1996) Karuta: sport or culture? Japan Quarterly 43, 67-77.

Butler, Yuko Goto and Iino, Masakazu (2005) Current Japanese reforms in English language education: The 2003 “Action Plan". Language Policy 4, 25-45.

Chomsky, Noam (1972) Language and Mind. New York: Harcourt Brace Jovanovich.

Davis, Christina (2012) "Is Jaffna Tamil the best?" Producing "legitimate" language in a multilingual Sri Lankan school. Journal of Linguistic Anthropology 22(2), E61E82.

Doi, Takeo (1973) The Anatomy of Dependence. Tokyo and New York: Kodansha International.

Downes, Simon (2001) Sense of Japanese cultural identity within an English partial immersion programme: should parents worry? International Journal of Bilingual Education and Bilingualism 4(3), 165-180.

Ellis, Rod (2002) The place of grammar instruction in the second/foreign language curriculum. In Eli Hinkel and Sandra Fotos (eds.), New Perspectives on Grammar Teaching in Second Language Classrooms, 17-34. Mahwah, NJ: Lawrence Erlbaum Associates.

Gottlieb, Nanette (2005) Language and Society in Japan. Cambridge: Cambridge University Press.

Gudykunst, William B., and Tsukasa Nishida (1994) Bridging Japanese/North American Differences. Los Angeles: Sage. 
Heath, Shirley Brice (1977) Social history. In Joshua A. Fishman (ed.), Bilingual Education: Current Perspectives, 53-72. Arlington, VA: Center for Applied Linguistics.

Hill, Jane (1985) The grammar of consciousness and the consciousness of grammar. American Ethnologist 12(4), 725-737.

Hippo Family Club (1985) Hippo goes overseas. Audio recording. Tokyo: LEX Institute.

Hippo Family Club (1997) Anyone can speak 7 languages! Audio recording. Tokyo: LEX Institute.

Hymes, Dell (2001) On communicative competence. In Alessandro Duranti (ed.), Linguistic anthropology: a reader 53-73. Malden, MA: Blackwell.

Inoue, Miyako (2006) Vicarious Language: Gender and Linguistic Modernity in Japan. Berkeley: University of California Press.

Irvine, Judith, and Susan Gal (2000) Language ideology and linguistic differentiation. In Paul Kroskrity (ed.), Regimes of Language: Ideologies, Polities, and Identities, 35-83. Santa Fe: School of American Research.

Krashen, Stephen (1982) Principles and Practice in Second Language Acquisition. New York: Pergamon Press.

Lenneberg, Eric H. (2004) Language in the context of growth and maturation. In Barbara Lust and Claire Foley (eds.), First Language Acquisition: The Essential Readings, 103-108. Philadelphia: Wiley-Blackwell.

LEX Institute (2007) 七刀国語を話す、日常がある。 [Speak seven languages, it's natural]. Hippo Family Club home page. http://www.lexhippo.gr.jp/

Lincicome, Mark (2009) Imperial Subjects as Global Citizens: Nationalism, Internationalism, and Education in Japan. Lanham, MD: Lexington Books.

McVeigh, Brian (1998) Linking state and self: how the Japanese state bureaucratizes subjectivity through moral education. Anthropological Quarterly 71(3), 125-35.

Maher, John C. (2001) Preface. In Mary Goebel Noguchi and Sandra Fotos (eds.), Studies in Japanese Bilingualism, vii-x. Clevedon: Multilingual Matters.

Miller, Roy Andrew (1982) Japan's Modern Myth: The Language and Beyond. New York: Weatherhill.

Nakane, Chie (1970) Japanese Society. Berkeley: University of California Press.

Ochs, Elinor, and Bambi Schieffelin (1984). Language acquisition and socialization: three developmental stories and their implications. In Culture Theory: Essays on Mind, Self, and Emotion, 276-320. New York: Cambridge University Press.

Omaggio Hadley, Alice (2001) Teaching Language in Context. Boston: Heinle \& Heinle.

Piller, Ingrid, and Kimie Takahashi (2006) A passion for English: desire and the language market. In A. Pavlenko (ed.) Bilingual Minds: Emotional Experience, Expression and Representation. Clevedon, UK: Multilingual Matters, pp.59 - 83.

Seargeant, Philip (2006) "More English than England itself": The simulation of authenticity in foreign language practice in Japan. International Journal of Applied Linguistics 15, 326-345.

Silverstein, Michael (1979) Language structure and linguistic ideology. In Paul Clyne, William Hanks, and Carol Hofbauer (eds.), The Elements, a Parasession on Linguistic Units and Levels, April 20-21 1979; Including Papers from the 
Conference on Non-Slavic Languages of the USSR, April 18 1979, 193-247. Chicago: Chicago Linguistic Society.

Sugimoto, Yoshio (1999) Making sense of nihonjinron. Thesis Eleven 57, 81-96.

Tomaselo, Michael (2003) Constructing a Language: A Usage-based Theory of Language Acquisition. Cambridge, MA: Harvard University Press.

Woolard, Kathryn (1998) Introduction: Language ideology as a field of inquiry. In

Language Ideologies: Practice and Theory. New York and Oxford: Oxford University Press.

Yamada, Haru (1997) Different Games, Different Rules: Why Americans and Japanese Misunderstand each Other. New York and Oxford: Oxford University Press

CHAD NILEP is an Adjunct Associate Professor with the Institute of Liberal Arts and Sciences at Nagoya University, Japan. His ethnographic and discourse-based research in multilingual settings includes work on code switching as well as identity in second language learning. In addition, he studies the political and ideological effects of discourse both in mass media and face-to-face interaction. He is the co-editor, with Adam Hodges, of Discourse, War and Terrorism (John Benjamins 2007).

Address: Institute of Liberal Arts and Sciences, Nagoya University, Furo-cho, Chikusa, Nagoya, 464-8601, Japan. email: nilep@ilas.nagoya-u.ac.jp 